Original paper

\title{
Determination of ferrous-ferric iron contents in tourmaline using synchrotron-based XANES
}

\author{
Elizabeth A. LEVY ${ }^{*}$, Darrell J. HENRY¹, Amitava ROY², Barbara L. DUTROW \\ ${ }^{1}$ Department of Geology and Geophysics, Louisiana State University, Howe Russell Geoscience Complex, Baton Rouge, La 70803, USA; \\ elevy5@lsu.edu \\ ${ }^{2}$ Center for Advanced Microstructures and Devices, Louisiana State University, 6980 Jefferson Hwy, Baton Rouge, La 70806, USA \\ * Corresponding author
}

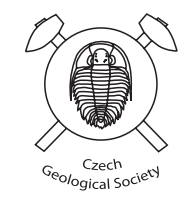

The complex geochemistry of tourmaline makes it an important tool in determining its formational environment. Typically, tourmaline chemistry is analyzed through electron-probe microanalysis (EPMA), but this analytical tool cannot determine directly the oxidation states of transition elements such as $\mathrm{Fe}\left(\mathrm{Fe}^{2+}, \mathrm{Fe}^{3+}\right)$. Direct quantitative measurement of these cations is important in minerals to acquire a more complete chemical characterization and informative structural formula. Synchrotron-based X-ray Absorption Near Edge Spectroscopy (XANES) is a method to directly measure $\mathrm{Fe}^{2+}$ and $\mathrm{Fe}^{3+}$ in minerals, including tourmaline. This method utilizes advances in software and detector technology to significantly decrease data processing time and errors.

Three tourmaline samples, dravite, povondraite, and oxy-schorl, analyzed by combining XANES and EPMA data, exhibit distinct ferrous-ferric contents using the pre-edge and absorption edge methods. These analyses reveal, respectively: 99.62-100 wt. $\% \mathrm{Fe}^{2+}$ in dravite, $12.5-20.00$ wt. $\% \mathrm{Fe}^{2+}$ vs. 87.48-100 wt. \% $\mathrm{Fe}^{3+}$ in povondraite, and $63.03 \mathrm{wt} . \% \mathrm{Fe}^{2+}$ vs. 36.98-36.41 wt. $\% \mathrm{Fe}^{3+}$ in schorl. Information on the oxidation states of Fe results in enhanced charge-balanced constraints that allow improved estimation of the $\mathrm{H}$ contents in the tourmaline and a more accurate designation of the structural formula and classification of tourmaline species. Thus, XANES is a viable technique to obtain oxidation states of transition elements in tourmaline.

Keywords: tourmaline, geochemistry, ferrous-ferric iron, synchrotron, XANES

Received: 21 October 2017; accepted: 4 June 2018; handling editor: J. Cempirek

\section{Introduction}

Tourmaline supergroup minerals are the most important borosilicate minerals in the Earth's crust (e.g. Dutrow and Henry 2011). They are geochemically complex with a general formula of $\mathrm{XY}_{3} \mathrm{Z}_{6}\left(\mathrm{~T}_{6} \mathrm{O}_{18}\right)\left(\mathrm{BO}_{3}\right)_{3} \mathrm{~V}_{3} \mathrm{~W}$. They can accommodate a range of major, minor and trace elements of various sizes and oxidation states (e.g. Hawthorne and Henry 1999; Henry et al. 2011). The most common ions (or vacancy) at each site are listed in Tab. 1. Most of the compositional variability occurs within the $\mathrm{X}, \mathrm{Y}$ and $\mathrm{Z}$ sites. The extensive variability in the tourmaline chemistry has resulted in definition of 33 species, to date (Henry and Dutrow 2017, this volume). Such chemical flexibility facilitates the wide use of tourmaline as an indicator of its host environment and the geologic processes involved during its formation (e.g. Henry and Dutrow 1996, this volume; Dutrow and Henry 2011).

The chemical composition of tourmaline is typically characterized by Electron Probe Microanalysis (EPMA). However, EPMA has limitations in that light elements such as $\mathrm{H}$ and Li cannot be measured, B analyses have a significant uncertainty, and the oxidation states of transition elements cannot be directly determined. For instance, in several tourmaline species iron is an essential component and the determination of this element's oxidation state is required to define the species properly (Tab. 1).

These facts create uncertainty in tourmaline geochemistry both in determining species and in calculating accurate structural formulae. In some instances, these elements can be approximated by making assumptions that rely on crystallographic and/or charge-balance considerations (e.g. B, Li, $\mathrm{H}$ and $\mathrm{Fe}^{3+}$; Henry and Dutrow 1996) or on regression of analytical data (e.g. Li in low$\mathrm{Mg}$ tourmaline; Pesquera et al. 2016). In the case of $\mathrm{Fe}^{3+}$, if light elements can be accurately measured, estimated, or inferred, it is possible to calculate $\mathrm{Fe}^{2+}$ and $\mathrm{Fe}^{3+}$ based on charge balance. This approach serves as a reasonable approximation for $\mathrm{Fe}^{3+}$, but is subject to considerable uncertainty (Henry and Dutrow 1996). Conversely, if the oxidation states of $\mathrm{Fe}$ can be directly determined, charge-balanced estimates of unanalyzed light elements, particularly $\mathrm{H}$, can be made with greater certainty.

There are two primary spectroscopic techniques that have been used for direct measurements of $\mathrm{Fe}^{3+}$ in minerals: Mössbauer spectroscopy and synchrotron-based X-ray Absorption Near Edge Spectroscopy (XANES). Mössbauer spectroscopy produces results for bulk pow- 
Tab. 1 Cations and anions occupying each site of tourmaline

\begin{tabular}{|c|c|c|}
\hline Site & $\begin{array}{l}\text { Relative abundance of ions } \\
\text { with different valence states }\end{array}$ & $\begin{array}{l}\text { Common cations and anions at each site in order of } \\
\text { relative abundance }\end{array}$ \\
\hline$X$ & $\mathrm{R}^{1+}>\mathrm{R}^{2+}>\square($ vacancy $)<$ & $\begin{array}{l}\mathrm{R}^{1+}: \mathbf{N a}^{1+}>>\mathrm{K}^{1+} \\
-\mathrm{R}^{2+}: \mathbf{C a}^{2+}\end{array}$ \\
\hline $\mathrm{Y}$ & $\mathrm{R}^{2+}>\mathrm{R}^{3+}>\mathrm{R}^{1+}>\mathrm{R}^{4+}$ & $\begin{array}{l}\mathrm{R}^{2+}: \mathbf{F e}^{2+} \sim \mathrm{Mg}^{2+}>\mathrm{Mn}^{2+}>>>\mathrm{Zn}^{2+}, \mathrm{Ni}^{2+}, \mathrm{Co}^{2+}, \mathrm{Cu}^{2+} \\
\mathrm{R}^{3+}: \mathbf{A l}^{3+}>>\mathbf{F e}^{3+}>\mathrm{Cr}^{3+}>>\mathrm{V}^{3+} \\
\mathrm{R}^{1+}: \mathbf{L i}^{1+} \\
\mathrm{R}^{4+}: \mathbf{T i}^{4+}\end{array}$ \\
\hline Z & $\mathrm{R}^{3+} \gg>\mathrm{R}^{2+}$ & $\begin{array}{l}-\mathrm{R}^{3+}: \mathbf{A l}^{3+}>>\mathbf{F e}^{3+}>\mathrm{Cr}^{3+}>\mathrm{V}^{3+} \\
-\mathrm{R}^{2+}: \mathbf{M g}^{2+}>>\mathrm{Fe}^{2+}\end{array}$ \\
\hline $\mathrm{T}$ & $\mathrm{R}^{4+}>\mathrm{R}^{3+}$ & $\begin{array}{l}-\mathrm{R}^{4+}: \mathbf{S i}^{\mathbf{4}^{+}} \\
-\mathrm{R}^{3+}: \mathbf{A l}^{3+}>\mathrm{B}^{3+}\end{array}$ \\
\hline B & $\mathrm{R}^{3+}$ & $-\mathrm{R}^{3+}: \mathbf{B}^{3+}$ \\
\hline V & $\mathrm{S}^{1-}>>\mathrm{S}^{2-}$ & $\begin{array}{l}\mathrm{S}^{1-}: \mathbf{O H}^{1-} \\
\mathrm{S}^{2-}: \mathbf{O}^{2-}\end{array}$ \\
\hline W & $\mathrm{S}^{1-} \sim \mathrm{S}^{2-}$ & $\begin{array}{l}\mathrm{S}^{1-}: \mathbf{O H}^{1-} \sim \mathbf{F}^{1-} \\
\mathrm{S}^{2-}: \mathbf{O}^{2-}\end{array}$ \\
\hline
\end{tabular}

Bolded are the most common ions

*The two sites ( $\mathrm{Y}$ and $\mathrm{Z}$ ) that accommodate Fe cations are highlighted. Modified from Henry et al. (2009) ders of Fe-bearing silicate minerals with an estimated precision of $\sim 3-6$ $\%$ of $\mathrm{Fe}^{3+} / \Sigma \mathrm{Fe}$ (e.g. Dyar et al. 2002). Two earlier synchrotron micro-XANES studies used beam sizes of $\sim 10 \times 15 \mu \mathrm{m}$ to determine in situ $\mathrm{Fe}^{2+}-\mathrm{Fe}^{3+}$ contents of a variety of Fe-bearing minerals, including tourmaline, and calibrated the $\mathrm{Fe}^{3+}$ contents on the pre-edge positions of standards to produce a calibration curve with estimated errors of $\sim 10 \%$ on the $\mathrm{Fe}^{3+} / \Sigma \mathrm{Fe}$ measurements (Dyar et al. 2002; Cempírek et al. 2006). Other calibration approaches for synchrotronbased XANES studies of powdered samples have used the area-normalized centroids of the pre-edge peak to determine the coordination environment and $\mathrm{Fe}^{3+} / \Sigma \mathrm{Fe}$ to an accuracy of $\sim \pm 10$ $\%$ (e.g. Galoisy et al. 2001; Petit et al. 2001; Wilke et al. 2001). The purpose of the current study is to use new-generation detectors in synchrotron-based XANES to obtain $\mathrm{Fe}^{3+} / \Sigma \mathrm{Fe}$ in selected tourmalines and to provide improved techniques for measurements using the absorption edge peak (Fig 1).

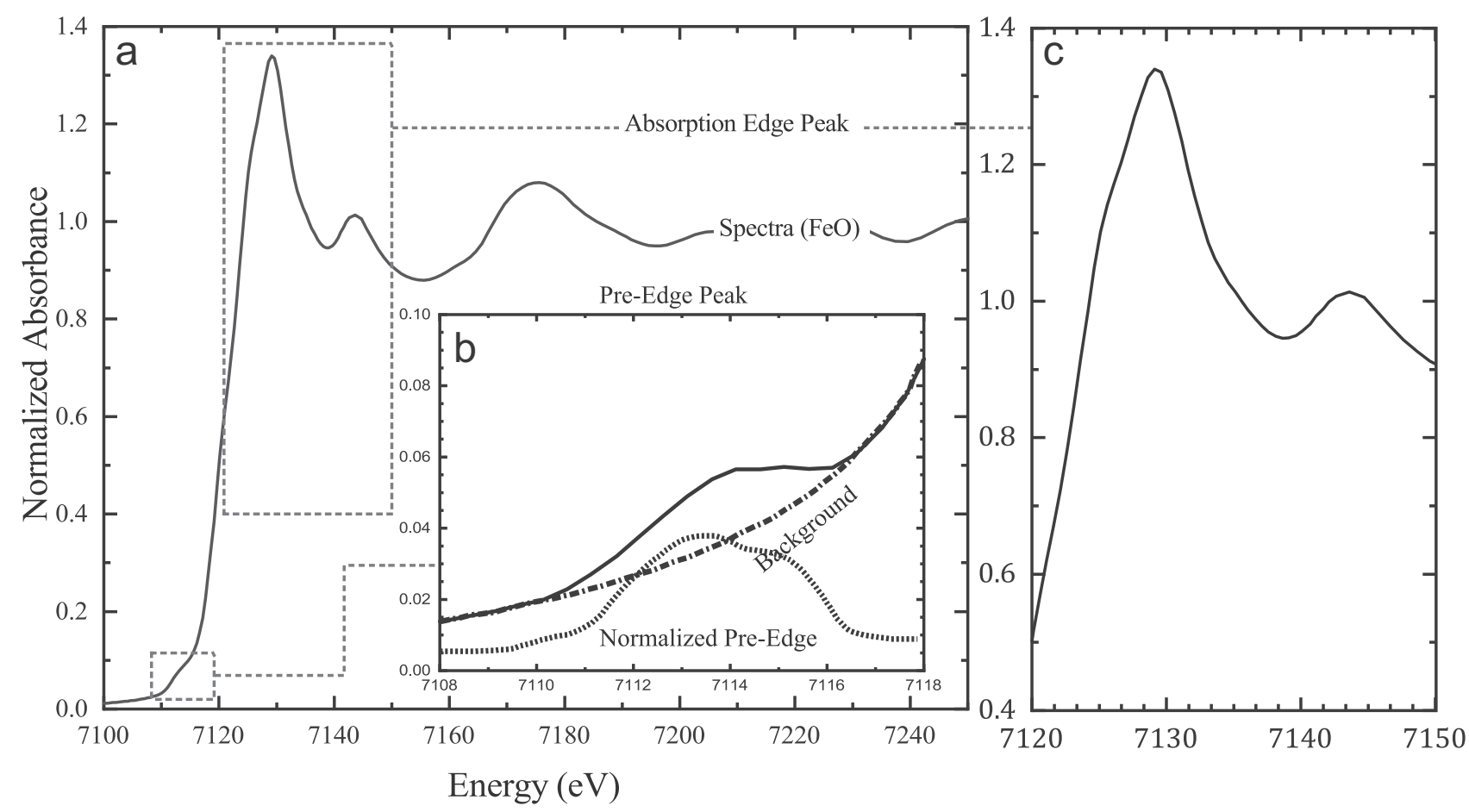

Fig. 1a Relative XANES spectrum (FeO). Areas of interest include the (b) Pre-Edge peak and the cubic spline background, which is subtracted from the projected background to obtain the net normalized intensity and the (c) Absorption edge peak normalized using the IFEFFIT method of Newville (2001). 


\section{Samples}

Three tourmaline samples from distinctly different formational environments, considered to have a range of $\mathrm{Fe}^{2+}$ and $\mathrm{Fe}^{3+}$ contents, are studied (Fig. 2).

Sample 1 is a tourmaline of a chlorite-tourmalinehornblende paragneiss from Newry, Maine, USA. The paragneiss is from a pegmatitic wall-rock and is composed of acicular, brown-green magnesio-hornblendeactinolite crystals intergrown with deep-green, foliated chlorite masses and with large $(2-5 \mathrm{~cm})$, elongated, darkbrown tourmaline crystals, and trace amounts of calcite, biotite, and pyrite (Henry and Dutrow 1990).

Sample 2 is black tourmaline from the type locality of povondraite in the Alto Chapare District of Bolivia. Here the tourmaline forms on highly metasomatized alkaline igneous xenolithic blocks embedded in an evaporitic salt dome (e.g. Žáček et al. 1998). The tourmaline develops as anhedral, black-deep brown, zoned crystals in a matrix of dolomite, magnesite, gypsum, anhydrite, and wagnerite.

Sample 3 is a single, blueblack tourmaline crystal from an unknown location in Brazil, presumed to have a pegmatitic origin, due to its large size (2 cm diameter) and euhedral crystal form.

\section{Methods}

\subsection{Sample preparation}

To ensure analysis of the same portion of the crystal, the samples were first cut and mounted

Fig. 2 Left column shows optical scans of thin sections. White box always indicates area of enlargement shown in photomicrograph (right). a-b - Sample 1 , tourmaline in a magnesio-hornblende matrix with anhedral chlorite clusters. c-d - Sample 2, tourmaline in matrix of dolomite, magnesite, gypsum, anhydrite, and wagnerite. e-f - Sample 3 , tourmaline with a dark black rim and blue-black core. All tourmalines in this study were zoned (highlighted with thick black lines), but largely inclusion free. into an epoxy plug. The plug was cut, epoxied to a slide, and then polished to a standard thickness of $30 \mu \mathrm{m}$ for EPMA. Optical examination with a petrographic microscope assessed optical zonation and identified any inclusions in the tourmaline crystals.

The remaining sample in the epoxy mount was removed, the tourmaline crystals separated, and crushed in a corundum ball mill. In order to improve sample purity, the milled sample was handpicked using a stereomicroscope to separate tourmaline from matrix and inclusion minerals. Samples were pulverized using a corundum ball mill and agate mortar and pestle, ground to a size of 1-2 $\mu \mathrm{m}$. The sample powders were poured onto the Kapton ${ }^{\mathrm{TM}}$ tape in a mound and the excess returned to the container to minimize orientation of the grains.
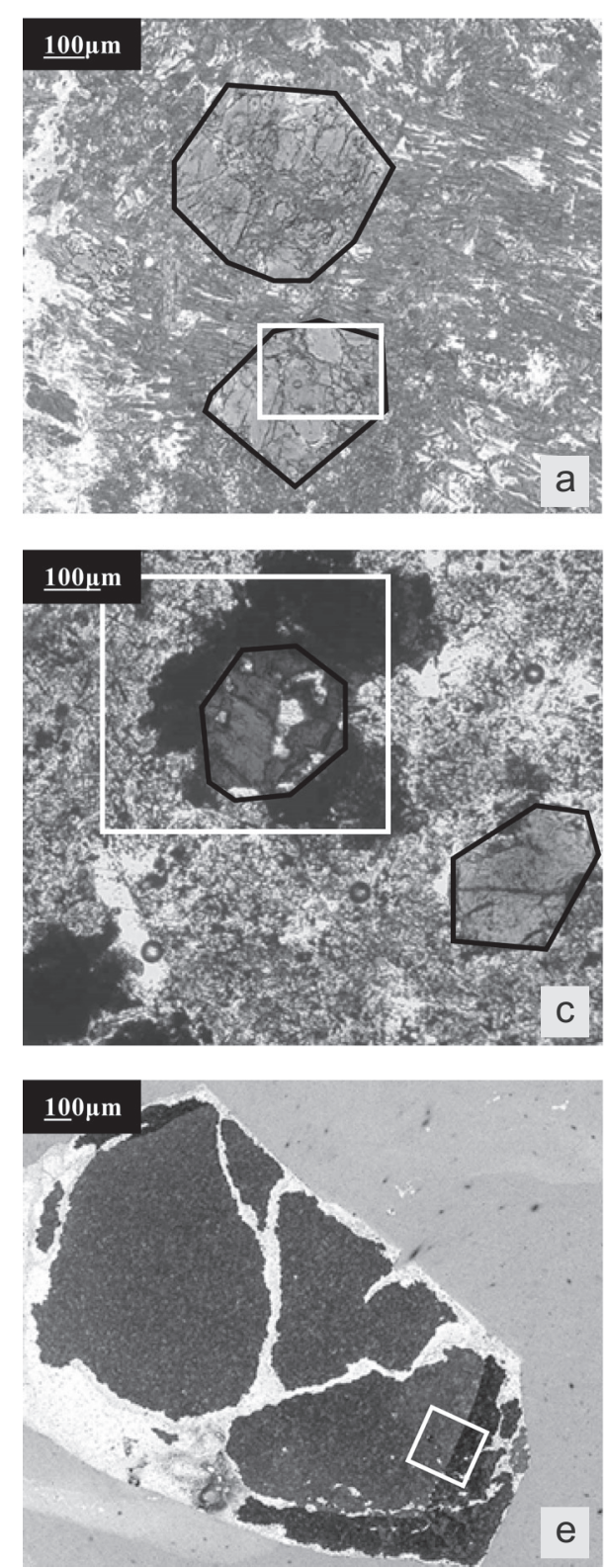
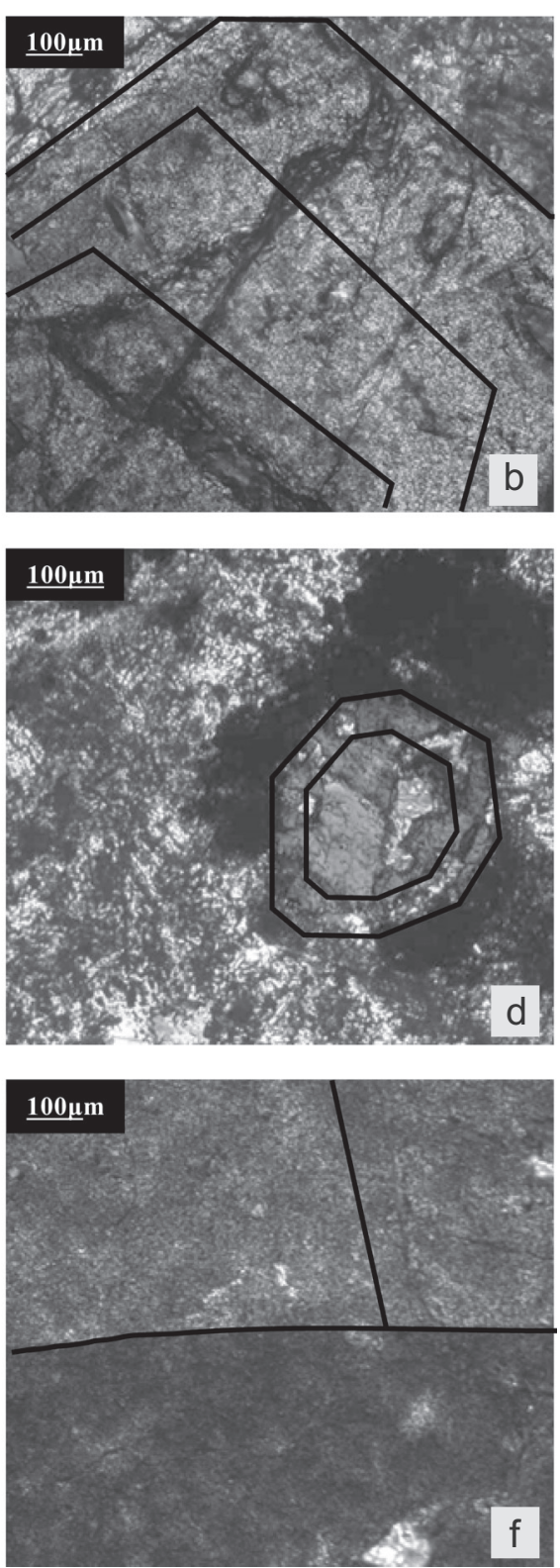


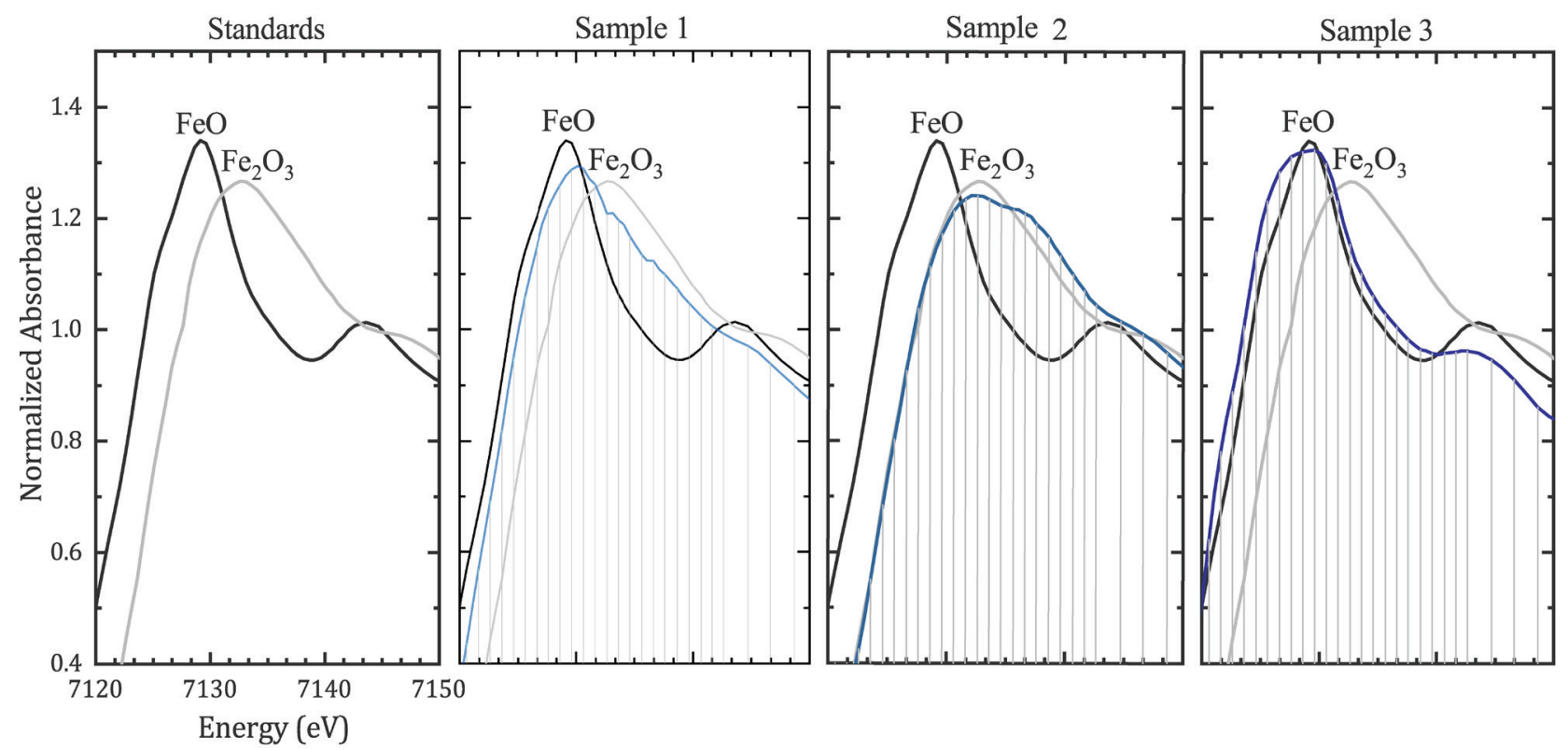

Fig. 3 The comparison of the $\mathrm{Fe} \mathrm{K}$ absorption edge spectra overlain on the $\mathrm{Fe}^{2+} \mathrm{O}$ and $\mathrm{Fe}^{3+}{ }_{2} \mathrm{O}_{3}$ standard spectra.

\subsection{Electron probe microanalyses (EPMA)}

Mineral chemistry was obtained with the JEOL JXA 8230 electron microprobe at Louisiana State University (LSU) using an accelerating potential of $15 \mathrm{kV}$, beam current of $20 \mathrm{nA}$, a $5 \mu \mathrm{m}$ spot size; the count times were $20-30 \mathrm{~s}$ for elements and $10-15 \mathrm{~s}$ for background. Tourmalines were analyzed for $\mathrm{Ca}, \mathrm{Na}, \mathrm{Mg}, \mathrm{Fe}, \mathrm{Si}, \mathrm{Al}, \mathrm{Ti}, \mathrm{Sn}, \mathrm{V}, \mathrm{Cr}, \mathrm{P}, \mathrm{Zn}$, $\mathrm{Cu}, \mathrm{Mn}, \mathrm{K}, \mathrm{F}$, and $\mathrm{Cl}$ using well-characterized natural or synthetic mineral standards: Toronto diopside $(\mathrm{Ca}, \mathrm{Mg}$, $\mathrm{Si}$ ), Rockport fayalite (Fe), Toronto rhodonite (Mn), Toronto rutile (Ti), Toronto albite $(\mathrm{Na})$, Toronto sanidine $(\mathrm{K})$, Smithsonian andalusite ( $\mathrm{Al})$, and Smithsonian fluorophlogopite (F). The elements $\mathrm{Cl}, \mathrm{P}, \mathrm{Cu}, \mathrm{V}$ and $\mathrm{Zn}$ were below detection limits of $0.02 \mathrm{wt}$. $\%$ under the analytical conditions used and are not included in the data tables. Where applicable, Li was estimated with the procedure of Pesquera et al. (2016). Measured and estimated oxide and anion data were normalized on the basis of $15 \mathrm{Y}+\mathrm{Z}$ $+\mathrm{T}$ cations in accordance with the procedures suggested by Henry and Dutrow (1996). For oxy-tourmalines, where the $\mathrm{W}$-site $\mathrm{O}$ is $>0.5$, the procedures of Bosi (2018) were used for distribution of cations between the $\mathrm{Y}$ and $\mathrm{Z}$ sites.

\subsection{X-Ray Absorption Near Edge Spectroscopy (XANES)}

The XANES measurements were conducted at the electron storage ring of J. Bennett Johnston Sr. Center for Advanced Microstructures and Devices (CAMD) at LSU. The ring operates at $1.3 \mathrm{GeV}$. Fe K-edge spectra of each specimen were recorded in fluorescence mode at the High Energy X-Ray Absorption Spectroscopy
(HEXAS) beamline. The $\mathrm{K}$ absorption edge of each spectrum was calibrated with the iron foil in the reference chamber. The beamline is located on a multi-pole wiggler with 11 poles operating at 5.5 Tesla. The beamline is equipped with a water-cooled Lemmonier-type double crystal monochromator; ${ }^{220} \mathrm{Ge}$ crystals were used for the measurement. The monochromator was calibrated with an iron foil from EXAFS Company to $7112 \mathrm{eV}$ and set to a step size of $0.45 \mathrm{eV}$ close to the edge. At this energy the monochromator has c. $2 \mathrm{eV}$ resolution. A Ketek ${ }^{\mathrm{TM}}$ seven element silicon detector array with a signal processor capable of a $0.1 \mu$ s peaking time was used for fluorescence measurement.

Three spectral runs with a beam size of $9 \times 1 \mathrm{~mm}$ were acquired from each unknown sample and averaged. These data were compared with single runs of the $\mathrm{FeO}$ and $\mathrm{Fe}_{2} \mathrm{O}_{3}$ reference standards. An iron foil was inserted between the second and third ion chambers to monitor energy calibration. Valence states are quantified using a linear peak fitting algorithm against known standard spectra of $\mathrm{FeO}$ and $\mathrm{Fe}_{2} \mathrm{O}_{3}$. Several spectra for individual samples and both reference standards of $\mathrm{FeO}$ and $\mathrm{Fe}_{2} \mathrm{O}_{3}$ were merged, then plotted (Fig. 3) and analyzed based on the positioning of the Fe K-Edge. Oxidation state quantitation was performed with PeakFit ${ }^{\mathrm{TM}}$. The XANES spectrum was first normalized using the ATHENA software (Ravel and Newville 2005) with the absorption edge set to 7111.2 (Wilke et al. 2001). The pre-edge section of the spectrum just below the absorption edge was then selected in PeakFit ${ }^{\mathrm{TM}}$ by Systat Software Incorporated (Quarteri et al. 2005). A cubic spline background was subtracted from this section to obtain the net intensity. Two Gaussian peaks were fitted to this region minimizing 
Tab. 2 Average of compositions (wt. \% and apfu) across traverses of the three tourmaline samples (EMPA supplemented by XANES)

\begin{tabular}{|c|c|c|c|c|c|c|c|}
\hline & \multicolumn{2}{|c|}{ Sample 1} & \multicolumn{2}{|c|}{ Sample 2} & \multicolumn{3}{|c|}{ Sample 3} \\
\hline & XANES A.E. & XANES N.E & XANES A.E. & XANES N.E. & All FeO & XANES A.E. & XANES N.E. \\
\hline $\mathrm{SiO}_{2}$ & $37.16(0.22)$ & $37.16(0.22)$ & $32.68(0.82)$ & $32.68(0.82)$ & $33.65(0.24)$ & $33.65(0.24)$ & $33.65(0.24)$ \\
\hline $\mathrm{Al}_{2} \mathrm{O}_{3}$ & $32.59(0.44)$ & $32.59(0.44)$ & $10.68(3.90)$ & $10.68(3.90)$ & $31.37(0.29)$ & $31.37(0.29)$ & $31.37(0.29)$ \\
\hline $\mathrm{TiO}_{2}$ & $0.18(0.07)$ & $0.18(0.07)$ & $1.75(1.02)$ & $1.75(1.02)$ & $0.81(0.07)$ & $0.81(0.07)$ & $0.81(0.07)$ \\
\hline $\mathrm{V}_{2} \mathrm{O}_{3}$ & $0.00(0.00)$ & $0.00(0.00)$ & $0.26(0.13)$ & $0.26(0.13)$ & $0.00(0.00)$ & $0.00(0.00)$ & $0.00(0.00)$ \\
\hline $\mathrm{Cr}_{2} \mathrm{O}_{3}$ & $0.04(0.04)$ & $0.04(0.04)$ & $0.03(0.03)$ & $0.03(0.03)$ & $0.01(0.01)$ & $0.01(0.01)$ & $0.01(0.01)$ \\
\hline $\mathrm{FeO}$ & $2.56(0.05)$ & $2.55(0.05)$ & $0.00(0.00)$ & $3.71(0.00)$ & $13.81(0.18)$ & $8.19(0.10)$ & $8.70(0.11)$ \\
\hline $\mathrm{Fe}_{2} \mathrm{O}_{3}$ & $0.00(0.00)$ & $0.01(0.00)$ & $33.00(6.17)$ & $28.87(5.40)$ & $0.00(0.00)$ & $6.25(0.08)$ & $5.68(0.07)$ \\
\hline $\mathrm{MnO}$ & $0.01(0.01)$ & $0.01(0.01)$ & $0.01(0.01)$ & $0.01(0.01)$ & $0.09(0.03)$ & $0.09(0.03)$ & $0.09(0.03)$ \\
\hline $\mathrm{MgO}$ & $9.81(0.28)$ & $9.81(0.28)$ & $7.00(0.79)$ & $7.00(0.79)$ & $2.46(0.06)$ & $2.46(0.06)$ & $2.46(0.06)$ \\
\hline $\mathrm{Li}_{2} \mathrm{O} *$ & $0.00(0.00)$ & $0.00(0.00)$ & $0.00(0.00)$ & $0.00(0.00)$ & $0.26(0.04)$ & $0.26(0.04)$ & $0.26(0.04)$ \\
\hline $\mathrm{CaO}$ & $1.65(0.36)$ & $1.65(0.36)$ & $0.02(0.02)$ & $0.02(0.02)$ & $0.58(0.03)$ & $0.58(0.03)$ & $0.58(0.03)$ \\
\hline $\mathrm{Na}_{2} \mathrm{O}$ & $1.80(0.07)$ & $1.80(0.07)$ & $2.32(0.25)$ & $2.32(0.25)$ & $2.26(0.05)$ & $2.26(0.05)$ & $2.26(0.05)$ \\
\hline $\mathrm{K}_{2} \mathrm{O}$ & $0.01(0.00)$ & $0.01(0.00)$ & $0.81(0.29)$ & $0.81(0.29$ & $0.06(0.01)$ & $0.06(0.01)$ & $0.06(0.01)$ \\
\hline $\mathrm{F}$ & $0.04(0.04)$ & $0.04(0.04)$ & $0.00(0.01)$ & $0.00(0.01)$ & $0.56(0.09)$ & $0.56(0.09)$ & $0.56(0.09)$ \\
\hline $\mathrm{B}_{2} \mathrm{O}_{3}^{*}$ & $10.72(0.04)$ & $10.72(0.04)$ & $9.51(0.24)$ & $9.51(0.24)$ & $10.15(0.05)$ & $10.15(0.05)$ & $10.15(0.05)$ \\
\hline $\mathrm{H}_{2} \mathrm{O}^{*}$ & $3.25(0.05)$ & $3.25(0.05)$ & $2.20(0.22)$ & $2.66(0.18)$ & $3.24(0.06)$ & $2.65(0.06)$ & $2.72(0.06)$ \\
\hline Total & $99.78(0.34)$ & $99.82(0.34)$ & $100.28(0.44)$ & $100.33(0.44)$ & $99.27(0.48)$ & $99.34(0.48)$ & $99.12(0.48)$ \\
\hline Si apfu & 6.024 & 6.024 & 5.971 & 5.971 & 5.763 & 5.763 & 5.763 \\
\hline${ }^{[4]} \mathrm{Al}$ & 0.000 & 0.000 & 0.029 & 0.029 & 0.237 & 0.237 & 0.237 \\
\hline Sum $T$ site & 6.024 & 6.024 & 6.000 & 6.000 & 6.000 & 6.000 & 6.000 \\
\hline${ }^{[3]} \mathrm{B}$ & 3.000 & 3.000 & 3.000 & 3.000 & 3.000 & 3.000 & 3.000 \\
\hline $\mathrm{Al}$ & 6.000 & 6.000 & 2.270 & 2.270 & 6.000 & 5.084 & 5.084 \\
\hline $\mathrm{Cr}$ & 0.000 & 0.000 & 0.004 & 0.004 & 0.000 & 0.000 & 0.000 \\
\hline V & 0.000 & 0.000 & 0.038 & 0.038 & 0.000 & 0.000 & 0.000 \\
\hline $\mathrm{Fe}^{3+}$ & 0.000 & 0.000 & 1.782 & 1.782 & 0.000 & 0.286 & 0.286 \\
\hline $\mathrm{Mg}$ & 0.000 & 0.000 & 1.906 & 1.906 & 0.000 & 0.630 & 0.629 \\
\hline Sum $Z$ site & 6.000 & 6.000 & 6.000 & 6.000 & 6.000 & 6.000 & 6.000 \\
\hline Al & 0.226 & 0.226 & 0.000 & 0.000 & 0.094 & 1.010 & 1.010 \\
\hline $\mathrm{Mg}$ & 2.371 & 2.371 & 0.000 & 0.000 & 0.630 & 0.000 & 0.000 \\
\hline $\mathrm{Ti}^{4}$ & 0.022 & 0.022 & 0.240 & 0.240 & 0.105 & 0.105 & 0.105 \\
\hline $\mathrm{Fe}^{2+}$ & 0.348 & 0.346 & 0.000 & 0.567 & 1.978 & 1.173 & 1.246 \\
\hline $\mathrm{Fe}^{3+}$ & 0.000 & 0.001 & 2.755 & 2.188 & 0.000 & 0.519 & 0.446 \\
\hline $\mathrm{Mn}^{2+}$ & 0.001 & 0.001 & 0.001 & 0.001 & 0.012 & 0.012 & 0.012 \\
\hline $\mathrm{Li}$ & 0.000 & 0.000 & 0.000 & 0.000 & 0.181 & 0.181 & 0.181 \\
\hline Sum $Y$ site & 2.976 & 2.976 & 3.000 & 3.000 & 3.000 & 3.000 & 3.000 \\
\hline $\mathrm{Ca}$ & 0.286 & 0.286 & 0.005 & 0.005 & 0.107 & 0.107 & 0.107 \\
\hline $\mathrm{Na}$ & 0.565 & 0.565 & 0.821 & 0.821 & 0.749 & 0.748 & 0.749 \\
\hline K & 0.001 & 0.001 & 0.190 & 0.190 & 0.013 & 0.013 & 0.013 \\
\hline Vacancy & 0.148 & 0.148 & 0.000 & 0.000 & 0.131 & 0.132 & 0.132 \\
\hline Sum $X$ site & 1.000 & 1.000 & 1.015 & 1.015 & 1.000 & 1.000 & 1.000 \\
\hline $\mathrm{OH}$ & 3.516 & 3.515 & 2.678 & 3.245 & 3.698 & 3.029 & 3.102 \\
\hline $\mathrm{F}$ & 0.022 & 0.022 & 0.001 & 0.001 & 0.302 & 0.302 & 0.301 \\
\hline $\mathrm{O}$ & 0.462 & 0.463 & 1.320 & 0.753 & 0.000 & 0.669 & 0.595 \\
\hline Sum $V, W$ sites & 4.000 & 4.000 & 4.000 & 4.000 & 4.000 & 4.000 & 4.000 \\
\hline
\end{tabular}

Calculated using XANES A.E. (absorption edge) or XANES N.E. (near edge) values for $\mathrm{Fe}^{2+} / \Sigma \mathrm{Fe}$ and $\mathrm{Fe}^{3+} / \Sigma \mathrm{Fe}$

$\mathrm{Zn}, \mathrm{Cu}, \mathrm{Cl}, \mathrm{Cr}$, and $\mathrm{V}$ below detection limits for most samples. Standard deviations in parentheses

*calculated (see Methods)

the residual with peak locations being allowed to float. White line peaks in the absorption edge, the intense absorption peak in the near-edge, were used for calibration following Ravel and Newville (2005). The XANES spectra were finally normalized using the IFEFFIT method of Newville (2001).

\section{Results}

\subsection{Electron Probe Microanalyses (EPMA)}

The three tourmaline samples exhibit a range of $\mathrm{Mg}$, $\mathrm{Fe}$, and $\mathrm{Al}$ contents. Averaged values of traverses across 
zones used for the XANES analysis are presented in Tab. 2. On an $\mathrm{Fe}-\mathrm{Al}-\mathrm{Mg}$ diagram the analyses fall near the dravite/oxy-dravite (sample 1), povondraite (sample 2), and schorl/oxy-schorl (sample 3) positions (Fig. 4). Sample 1 has relatively low total Fe contents, 0.35 atoms per formula unit (apfu), and it was originally assumed that all $\mathrm{Fe}$ is $\mathrm{Fe}^{2+}$ (Henry and Dutrow 1990). Sample 2, from the povondraite type locality, is rich in $\mathrm{Fe}(\sim 33.00$ apfu $\mathrm{Fe})$. Compositional systematics show that it is inversely correlated with $\mathrm{Al}$, consistent with homovalent substitution of $\mathrm{Fe}^{3+}$ for $\mathrm{Al}$ and that the $\mathrm{Fe}$ is likely to be predominantly $\mathrm{Fe}^{3+}$ (Žáček et al. 1998; Henry and Dutrow 2012). Sample 3 is relatively Fe-rich $(\sim 2.00$ apfu Fe) and falls close to the schorl/ oxy-schorl end-member composition on the $\mathrm{Fe}-\mathrm{Al}-\mathrm{Mg}$ plot (Fig. 2).

\subsection{X-Ray Absorption Near Edge Spectroscopy (XANES)}

For the pre-edge peak procedure, the XANES spectra are interpreted for $\mathrm{Fe}^{2+}$ and $\mathrm{Fe}^{3+}$ contents and given in Tab. 3 . Based on the peak centroid, sample 1 has $99.6 \mathrm{wt}$. \% $\mathrm{Fe}^{2+}$ of total iron, sample $212.5 \% \mathrm{Fe}^{2+}$ and sample $363.0 \%$ $\mathrm{Fe}^{2+}$. The intensity of the spectra is not constant across all samples, indicating that the Fe is likely in distinct coordination environments.

In terms of the Fe absorption edge, sample 1 precisely coincides with the Fe peak measured on the $\mathrm{FeO}$ standard and is interpreted as $100 \% \mathrm{Fe}^{2+}$. The Fe peak of sample 2 is coincident with the $\mathrm{Fe}$ peak position of the $\mathrm{Fe}_{2} \mathrm{O}_{3}$ standard and is interpreted as entirely $\mathrm{Fe}^{3+}$. In contrast,

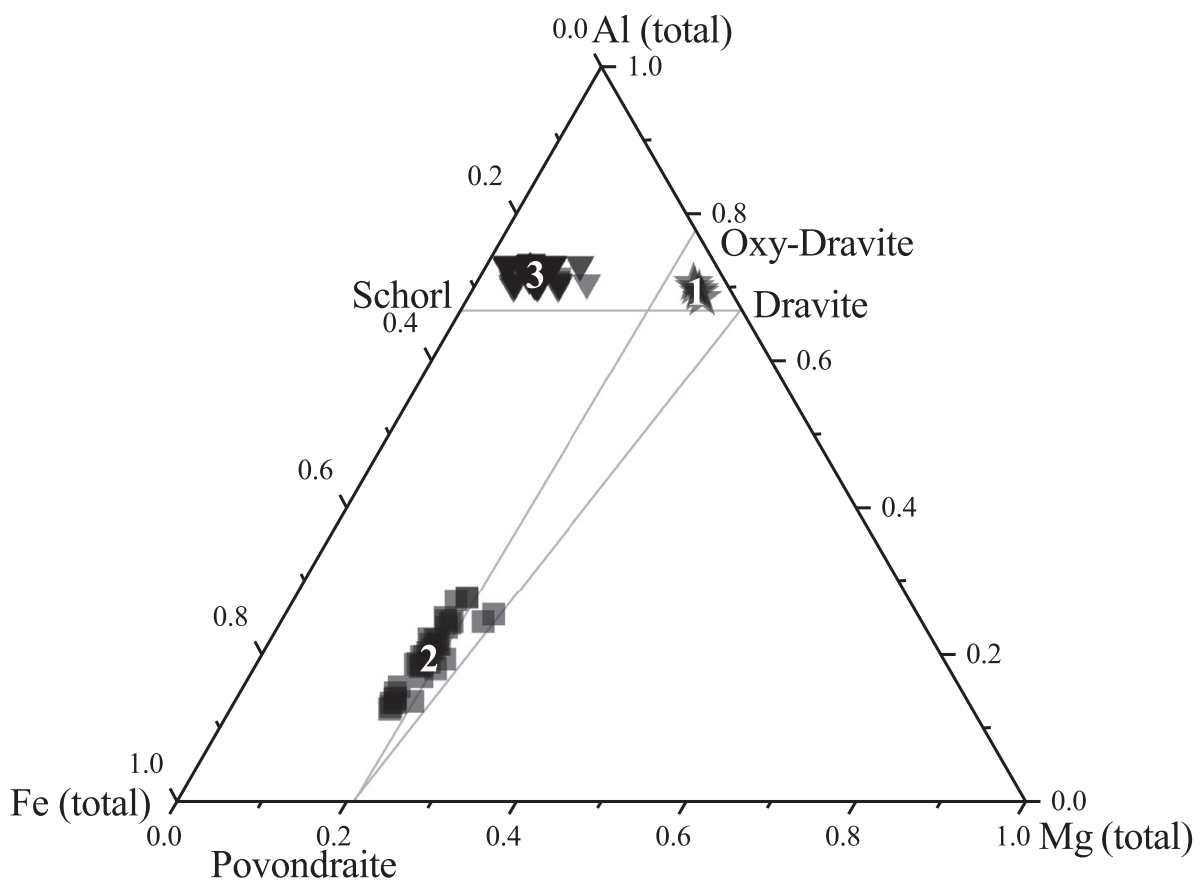

sample 3 has a peak that lies between the two standards suggesting that both $\mathrm{Fe}^{2+}$ and $\mathrm{Fe}^{3+}$ are present.

The bulk ratios of $\mathrm{Fe}^{3+} / \Sigma \mathrm{Fe}$ and $\mathrm{Fe}^{2+} / \Sigma \mathrm{Fe}$ for sample 3 were determined from the normalized spectral peaks using a linear combination-fitting procedure of the absorption edge peak locations. Sample 3 was calculated to have $59.3 \% \mathrm{Fe}^{2+}$ and $40.7 \% \mathrm{Fe}^{3+}$ of the total $\mathrm{Fe}$. The precision of the computed ratio obtained from the linear fit to the spectra is calculated to be less than $2.4 \%$ relative to the $\mathrm{Fe}^{2+} / \Sigma \mathrm{Fe}$ and $\mathrm{Fe}^{3+} / \Sigma \mathrm{Fe}$.

\section{Discussion}

The pre-edge and absorption edge Fe oxidation state determinations are somewhat different, but generally similar. For example, the sample 2 (povondraite) has a total $\mathrm{Fe}^{3+} / \Sigma \mathrm{Fe}$ being $87.48 \%$ and $100 \%$, respectively, for these two approaches. This difference can be attributed to the influence of the coordination environment on the spectra such that there are distinctions between the two octahedral environments of the $\mathrm{Y}$ and $\mathrm{Z}$ sites that accommodate $\mathrm{Fe}^{3+}$, particularly in povondraite.

In practice dravitic tourmaline can have mixed $\mathrm{Fe}$ valence (e.g. Henry and Dutrow 1996), but the XANES data here indicate that the $\mathrm{Fe}$ is entirely $\mathrm{Fe}^{2+}$. In contrast, the schorl sample exhibits mixed Fe valence likely indicative of $\mathrm{Fe}$ availability and oxidation conditions within the host pegmatite.

With the inclusion of the XANES data, samples 1-3 can be optimally classified as Ca-rich dravite, povondraite and oxy-schorl, respectively. If it is assumed that all $\mathrm{Fe}$ is $\mathrm{FeO}$ in sample 3, the tourmaline is classified as a schorl. For the dravite and povondraite samples, the stoichiometric formulae are consistent with the $\mathrm{Fe}^{2+}-\mathrm{Fe}^{3+}$ assumptions used in previous studies (Henry and Dutrow 1990; Žáček et al 1999). Povondraite is generally considered to contain almost exclusively $\mathrm{Fe}^{3+}$ and the XANES data presented here are consistent with that assumption.

Using the measured $\mathrm{Fe}^{3+} / \Sigma \mathrm{Fe}$ obtained from the absorption

Fig. 4 Compositional data for the tourmaline samples studied labelled by their numbers. Diagonal lines represent the typical solid-solution ranges among oxy-dravite, povondraite, and dravite (Henry et al. 1999). Dravite data taken from Henry and Dutrow (1990). 
edge (A.E.) and pre-edge (P.E.), the charge-balance calculations for $\mathrm{H}$ and the $\mathrm{Y}$ - and $\mathrm{Z}$-site order-disorder procedure for oxy-tourmalines of Bosi (2018), improved average structural formulae are proposed (Tab. 4). The inclusion of $\mathrm{Fe}^{3+} / \Sigma \mathrm{Fe}$ and $\mathrm{Fe}^{2+} / \Sigma \mathrm{Fe}$ with the EPMA data for each sample allows more accurate structural formulae to be calculated because the $\mathrm{H}$ contents are better constrained. Thus, a more accurate tourmaline species designation is determined. As noted by Henry and Dutrow (1996), tourmalines with even moderate amounts of $\mathrm{Mg}$ typically have negligible $\mathrm{Li}$, and $\mathrm{B}$ site can generally be assumed to have $3 \mathrm{~B}$ apfu for low-Li tourmaline. However, sample 3 does appear to have small, but noteworthy amounts of Li based on the estimation procedures of Pesquera et al. (2016).

\section{Conclusions}

These data sets highlight the extensive ranges of $\mathrm{Fe}^{3+}$ and $\mathrm{Fe}^{2+}$ in tourmaline. Normalization of Fe-bearing tourmaline without knowledge of the oxidation state of $\mathrm{Fe}$ can result in structural formulae and classification with considerable errors. Synchrotron-based XANES measurements allow accurate determination of oxidation state of $\mathrm{Fe}$ in tourmaline so that the common practice of assuming that all $\mathrm{Fe}$ is $\mathrm{Fe}^{2+}$ or $\mathrm{Fe}^{3+}$ when calculating stoichiometry can be avoided and errors reduced. Consequently, the tourmaline species and crystal structure are more accurately determined.

There is a significant amount of time involved to process the pre-edge data that depends on site environments. For samples of a similar known site geometry, it is preferential to use the absorption-edge peak location. The XANES absorption-edge data can be obtained and processed same-day, delivering rapid results, an advantage over pre-edge data. The degree of confidence is greater than $95 \%$ compared to pre-edge analysis yielding mere $90 \%$.

Other methods that make determinations of Fe oxidation ratios within tourmaline, such as Mössbauer spectroscopy, also involve extensive interpretation, and may have greater error. While wet chemical analyses can be highly accurate and precise, they are laborious and time consuming. Thus coupling EPMA data with XANES is a powerful approach to obtain more complete chemical data on tourmaline, improving our interpretation of the mineral chemistry and, thereby, enhancing our understanding of the formational environments of tourmaline.

Acknowledgements. This manuscript was greatly improved by comments from anonymous reviewers and the editors, Jan Cempírek of Masaryk University, Brno, and both Vojtěch Janoušek and Irena Sedlačková of the Czech Geological Survey. We are immensely grateful to Jan Cempírek, Milan Novák, and Petr Gadas for the opportunity to present this research at the Tourmaline 2017 International Symposium and for discussions that

Tab. 4 Comparative formulae for each tourmaline sample using different XANES techniques

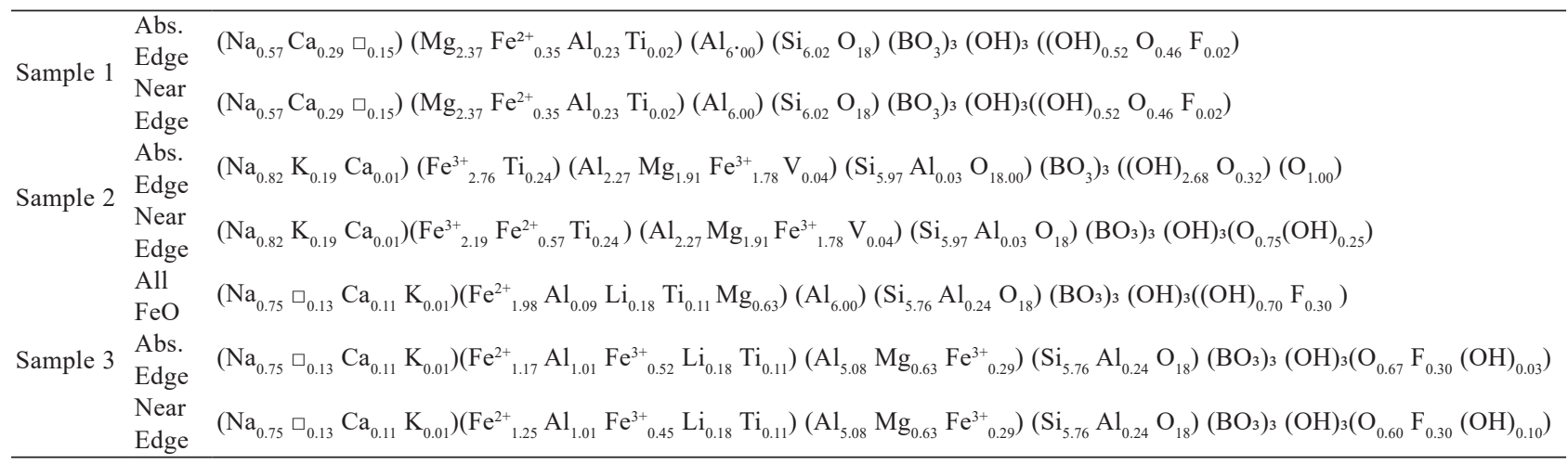

Formulae for samples 1, 2, and 3, showing the variance between the Absorption Edge (Abs. Edge) and Near Edge values. For comparison of the effect that $\mathrm{Fe}^{3+} / \Sigma \mathrm{Fe}$ vs. $\mathrm{Fe}^{2+} / \Sigma \mathrm{Fe}$ has on formula calculation, values calculated with all $\mathrm{Fe}$ as $\mathrm{FeO}$ can be viewed under sample 3 . 
improved the study. This project benefitted from access to the EPMA facility in the Chevron Geomaterials Characterization lab in the Shared Instrument Facility (SIF) at LSU as well as the LSU CAMD synchrotron beamline. The Ketek ${ }^{\mathrm{TM}}$ seven-element silicon drift detector array used in this study for fluorescence X-ray measurements at CAMD was acquired with funds provided by The Louisiana Board of Regents (LEQSF(2016-17)-ENH-TR-07). Nele Muttik guided the EPM analyses and Wanda Leblanc assisted with sample preparation. The CAMD staff greatly assisted in this study, especially Orhan Kizilkaya. Funding for this research is gratefully acknowledged from NSF grant \#1551434 (Dutrow and Henry) and the AAPG student W. David Wiman Memorial Grant (Levy). We are thankful for scholarship provided from the American Federation of Mineralogical Societies and Southeastern Geophysical Society (Levy). Travel funding for participation in the Tourmaline 2017 Conference was graciously provided through Louisiana State University Dean's Travel Award (Levy).

\section{References}

Bosi F (2018) Tourmaline crystal chemistry. Amer Miner 103: 298-306

Cempírek J, Novák M, Ertl A, Hughes JM, Rossman GR, DYAR MD (2006) Fe-bearing olenite with tetrahedrally coordinated Al from an abyssal pegmatite at Kutná Hora, Czech Republic: structure, crystal chemistry, optical and XANES spectra. Canad Mineral 44: 23-30

Dutrow BL, Henry DJ (2011) Tourmaline: a geologic DVD. Elements 7: 301-306

Dyar MD, Lowe EW, Guidotti CV, Delaney JS (2002) $\mathrm{Fe}^{3+}$ and $\mathrm{Fe}^{2+}$ partitioning among silicates in metapelites: a synchrotron micro-XANES study. Amer Miner 87: 514-522

Galoisy L, Calas G, Arrio MA (2001) High-resolution XANES spectra of iron in minerals and glasses: structural information from the pre-edge region. Chem Geol 174: 307-319

Hawthorne FC, Henry DJ (1999) Classification of the minerals of the tourmaline group. Eur J Mineral 11: 201-215

Henry DJ, Dutrow BL (1990) Ca substitution in Li-poor aluminous tourmaline. Canad Mineral 28: 111-124
Henry DJ, Dutrow BL (1996) Metamorphic tourmaline and its petrologic applications. In: Grew ES, ANOvitz LM (eds) Boron: Mineralogy, Petrology and Geochemistry. Mineralogical Society of America Reviews in Mineralogy 33: 503-557

Henry DJ, Dutrow BL (2012) Tourmaline at diagenetic to low-grade metamorphic conditions: its petrologic applicability. Lithos 154: 16-32

Henry DJ, Dutrow BL (2017) Twenty years of progress: advances in tourmaline studies since the Tourmaline 1997 Conference. In: GADAs P, NovÁK M (eds) Tourmaline 2017 International Symposium. Tiskový Express, Zlín, pp 40-43

HeNRY DJ, Dutrow BL (2018) Tourmaline studies through time: contributions to scientific advancements. J Geosci 63: 77-98

Henry DJ, KiRKLAND BL, KirKLAND DW (1999) Sectorzoned tourmaline from the cap rock of a salt dome. Eur J Mineral 11: 263-280

Henry DJ, Novák M, Hawthorne FC, Ertl A, Dutrow BL, Uher P, Pezzotta F (2011) Nomenclature of the tourmaline supergroup minerals. Amer Miner 96: 895-913

NeWviLle, M. (2001) IFEFFIT: interactive XAFS analysis and FEFF fitting. J Synchrotron Radiat 8: 322-324

Pesquera A, Gil-Crespo PP, Torres-Ruiz F, Torres-Ruiz J, RoDA-Robles E (2016) A multiple regression method for estimating $\mathrm{Li}$ in tourmaline from electron microprobe analyses. Mineral Mag 80: 1129-1133

Petit PE, Farges F, Wilke M, Sole VA (2001) Determination of the iron oxidation state in Earth materials using XANES pre-edge information. J Synchrotron Rad 8: 952-954

Quarteri S, Riccardi MP, Messiga B, Boscherini F (2005) The ancient glass production of the Medieval Val Gargassa glasshouse: Fe and Mn XANES study. J Non-Crystalline Solids 351: 3013-3022

Ravel B, Newville M (2005) ATHENA, ARTEMIS, HEPHAESTUS: data analysis for X-ray absorption spectroscopy using IFEFFIT. J Synchrotron Radiat 12: 537-541

Wilke M, Farges F, Petit PE, Brown Jr GE, Martin F (2001) Oxidation state and coordination of Fe in minerals: an Fe K-XANES spectroscopic study. Amer Miner 86: 714-730

ŽÁČEK,V, Petrov A, HYrŠL J (1998) Chemistry and origin of povondraite-bearing rocks from Alto Chapare, Cochabamba, Bolivia. J Czech Geol Soc 43: 59-67 